University of Michigan Law School

University of Michigan Law School Scholarship Repository

Law \& Economics Working Papers

7-1-2017

\title{
The Fiction of Locally Owned Mom and Pop Car Dealers: Some Data on Franchised Automobile Distribution in the State of Michigan
}

Daniel A. Crane

University of Michigan - Ann Arbor, dancrane@umich.edu

Follow this and additional works at: https://repository.law.umich.edu/law_econ_current

Part of the Law and Economics Commons

Working Paper Citation

Crane, Daniel A., "The Fiction of Locally Owned Mom and Pop Car Dealers: Some Data on Franchised Automobile Distribution in the State of Michigan" (2017). Law \& Economics Working Papers. 134.

https://repository.law.umich.edu/law_econ_current/134

This Article is brought to you for free and open access by University of Michigan Law School Scholarship Repository. It has been accepted for inclusion in Law \& Economics Working Papers by an authorized administrator of University of Michigan Law School Scholarship Repository. For more information, please contact mlaw.repository@umich.edu. 
The Fiction of Locally Owned Mom and Pop Car Dealers: Some Data on Franchised Automobile Distribution in the State of Michigan

\author{
Daniel A. Crane \\ University of Michigan Law School
}

The State of Michigan is currently defending a constitutional challenge to its automobile direct distribution prohibition. The lawsuit was brought by the automotive manufacturer Tesla, which has been denied a license to open show rooms or service centers in the state. A 2014 amendment to Michigan's vehicle franchise statute tightened the statute's direct distribution prohibition to make clear that even a manufacturer like Tesla that did not franchise dealers at all is prohibited from opening its own showrooms or service centers and dealing directly with consumers in the state. ${ }^{1}$ That law has been widely criticized by economists, consumer protection organizations like the Federal Trade Commission and Consumer Federation of America, environmental groups like the Sierra Club, and free market organizations like the Institute for Justice. ${ }^{2}$

In the Michigan litigation, the State is expected to rely on the assertion, frequently made by the dealers' lobbyists, that maintaining a locally owned dealership system is beneficial to the State. Such assertions are grounded in the trope of the atomistic "mom and pop" dealer of American economic folklore - the family-owned, locally rooted dealership. This justification is increasingly a fiction. While some such dealerships may still exist, Michigan law does not require dealerships to be locally owned and operated or independent from other economic enterprises. Many are not.

As I have detailed elsewhere, dealerships are increasingly organized into large, multi-state businesses with billions of dollars in revenues. ${ }^{3}$ The six largest dealer groups in the United States each had 2016 revenues exceeding Tesla's. ${ }^{4}$ For example, the Penske Automotive Group based in Bloomfield Hills, Michigan (which operates

\footnotetext{
${ }^{1}$ See Daniel A. Crane, Tesla, Dealer Franchise Laws, and the Politics of Crony Capitalism, 101 Iowa L. Rev. 573 (2016).

${ }^{2}$ Marina Lao et al., Fed. Trade Comm'n, Direct-to-Consumer Auto Sales: It's Not Just About Tesla, FTC Blogs: Competition Matters (May 11, 2015, 11:00 AM), https://www.ftc.gov/newsevents/blogs/competition-matters/2015/05/direct-consumer-auto-sales-its-not-just-about-tesla; Consumer Federation of America, Sierra Club, and Institute for Justice, Am. Antitrust Inst. et al., Sign-on Statement to State Government Leaders About the Anti-Consumer Effects of Laws Prohibiting Direct Distribution of Automobiles (2015), http://www2.itif.org/2015-tesla-big-tent-letter.pdf.

${ }^{3} I d$.

${ }^{4}$ Automotive News, ToP 150 DeALERSHIP

GROUPS (2017), http://www.autonews.com/assets/PDF/CA109608327.PDF.
} 
motorcycle dealerships but no automobile dealerships in Michigan), had over $\$ 20$ billion in annual revenues, almost three times Tesla's total 2016 revenue. ${ }^{5}$

The Appendix below, drawn from the Auto News 2016 rankings and additional information provided on dealer websites, shows the largest dealer groups with automobile dealerships in Michigan. Most of these groups span multiple states. Five of the groups operate more than 10 dealerships in the state. The largest, the Suburban Collection, operates 47 new car dealerships and 10 additional auto-related service centers in Michigan and had $\$ 2.3$ billion in revenue in 2016. The largest non-Michigan based dealer group operating in Michigan, the Ken Garff Automotive Group, operates three dealerships in Michigan out of the 55 total dealerships it operates and had over $\$ 4.3$ billion in revenue in 2016.

In light of these data, the argument that the State's interest in local ownership provides a legitimate public policy basis for a direct distribution prohibition is increasingly far-fetched. The actual data suggest that Michigan customers often purchase cars from multi-billion dollar organizations controlling tens or scores of dealerships spread across a wide geographic area.

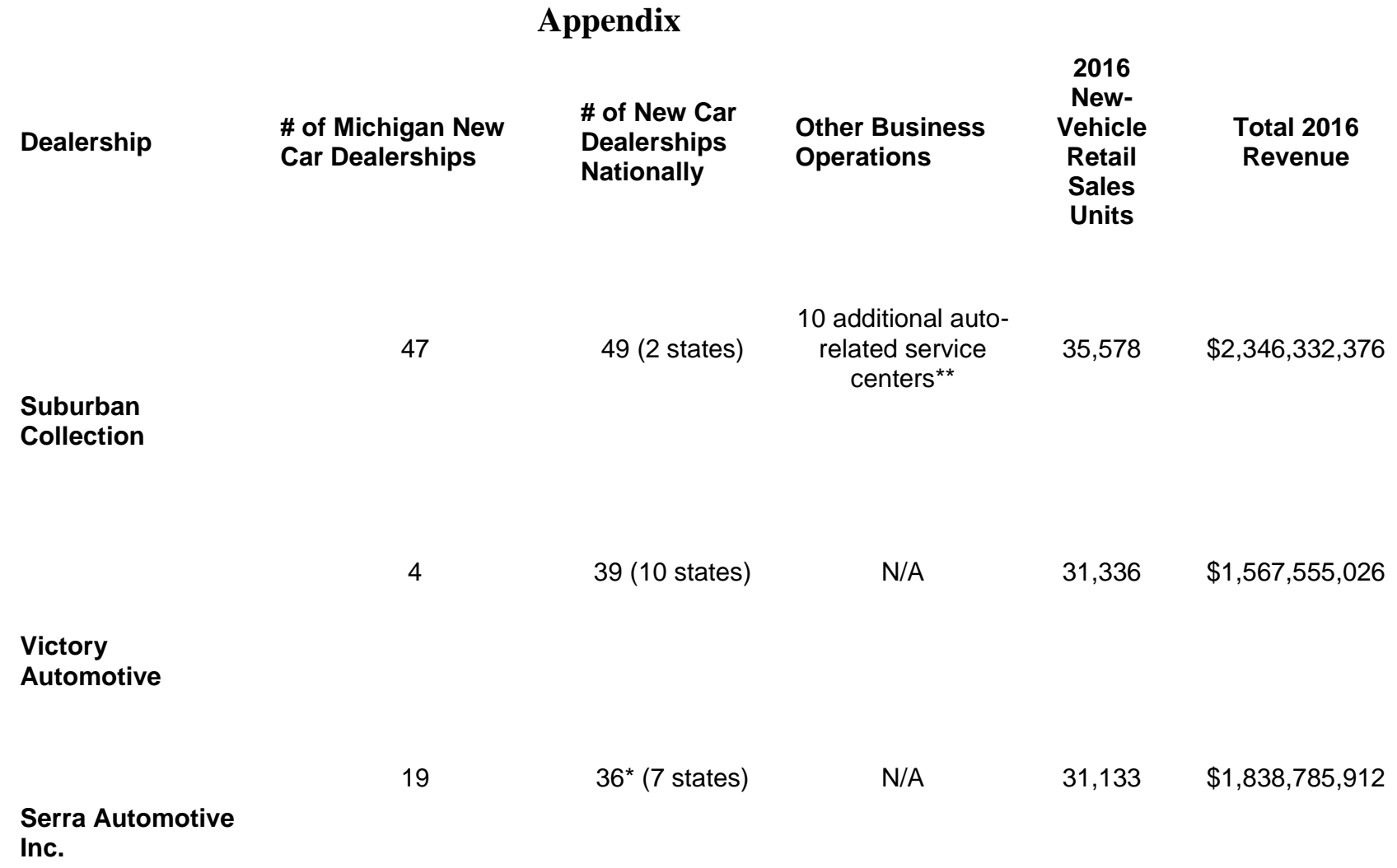

${ }^{5} I d$. 
1)Motorsports

dealership and

action park 2) auto

parts store 3 ) 3

finance companies

4) leasing firms 5)

insurance firms

5 additional autorelated service centers ${ }^{\star *}$
Zeigler Auto

Group

15

LaFontaine

Automotive Group
14,378

$\$ 1,000,225,535$

15

13,865

$\$ 863,260,786$

13 additional autorelated service centers ${ }^{\star *}$

12,762

$\$ 538,410,290$

21 (2 states)

\section{Fox Motors}

Automotive Group

70,893

$\$ 4,339,674,890$
10,843

$\$ 894,415,934$

6,595

$\$ 349,408,987$

6,094

$\$ 360,658,677$
5

12 (4 states)

Garbar

Management

Group

Stewart

Management

Group Inc.

Prestige

5

Sellers Auto

3

Group

3

55 (6 states)

N/A

Ken Garff

1)Gateway Financial

(subprime auto financing) 2)RightWay

Automotive Credit

2 additional autorelated centers ${ }^{\star *}$

3 additional autorelated centers ${ }^{* *}$

2 additional autorelated centers ${ }^{\star *}$
Moran Automotive Group

Todd Wenzel

4

4

3

Automotive
3
1 additional autorelated center** 